\title{
Assay of materials used in immunofluorescence techniques $^{1}$
}

\author{
W. D. BRIGHTON
}

From the Central Public Health Laboratory, Colindale, London

SYNOPSIS Samples of commercially available fluorescein isothiocyanate and conjugated antispecies globulins were evaluated. Only one of the samples was of very high quality. There was great variation in the quality of the conjugated globulin solutions and even the best of them showed defects.

Workers who use fluorescent antibody techniques recognize that many of the discrepancies between the results obtained in different laboratories, or in the same laboratory at different times, may be due to variations in the quality of the reagents used. The commercially available reagents are costly, so that extensive comparisons in each laboratory would be wasteful. An investigation was therefore carried out in which the properties of the reagents were measured objectively and related to price.

\section{SUPPLIERS}

Samples were purchased through the normal commercial channels, without giving to the suppliers any indication that the materials were required for assay. One sample from each supplier was included in the tests since it was felt that such expensive materials should have been released to the market only if the manufacturers were satisfied that their quality was uniformly high.

There were seven suppliers of fluorescein isothiocyanate, as follows: British Drug Houses Ltd., KochLight Laboratories Ltd., Edward Gurr Ltd., and George T. Gurr Ltd. (Britain); Baltimore Biological Laboratories, California Biochemicals, and Nutritional Biochemicals (U.S.A.).

Six samples of conjugated globulins were purchased: from Burroughs Wellcome \& Co., rabbit antihuman and goat anti-rabbit; Stayne Laboratories Ltd., goat antihuman and goat anti-rabbit; Baltimore Biologicals Ltd., goat anti-human and goat anti-rabbit.

The samples of fluorescein isothiocyanate were coded, not in the order given above, with the letters A-G, and the globulin samples, again not in the order given above, with the figures I to VI. These code letters and figures will be used throughout this publication. The object of pub-

Received for publication 15 February 1966

${ }^{1}$ A report to the Public Health Laboratory Service Immunofluorescence Study Group. lishing the results of the enquiry is not to identify the makers of unsatisfactory products, but to draw the attention both of manufacturers and of potential users to methods that can be used for assaying the quality of reagents used in immunofluorescence work.

\section{METHODS}

The samples of fluorescein isothiocyanate and globulin solutions were assayed by three techniques, each of which measured a different parameter. For the samples of fluorescein isothiocyanate, the techniques were (1) thin-layer chromatography on silica gel, (2) infra-red spectroscopy, and (3) activation and emission spectrophotometry, but for the samples of globulins (1) thinlayer chromatography on Sephadex G200 dextran gel, (2) immuno electrophoresis in agarose gel, and (3) activation and emission spectrophotometry were used.

In addition, quantitative assays of protein concentration and fluorescein-protein ratios were made on the globulin solutions, and the amount of emitted light was measured both from the globulin solutions and from solutions made with the samples of fluorescein isothiocyanate.

Finally, the properties of sera conjugated with each of the fluorescein isothiocyanate samples were compared.

\section{QUALITATIVE ASSAYS}

1 THIN-LAYER CHROMATOGRAPHY Glass plates carrying a layer of activated silica gel $0.2 \mathrm{~mm}$. thick were 'spotted' with equal strength solutions of each of the seven fluorochromes dissolved in acetone and also with free fluorescein, aminofluorescein, nitrofluorescein and pure fluorescein isothiocyanate isomers I and II. The plates were developed in the ascending mode with ethyl methyl ketone saturated with magnesium chloride and acetate.

Glass plates with a layer of Sephadex G200 dextran gel $0.4 \mathrm{~mm}$. thick were 'spotted' with equal strength solutions of each of the globulin solutions, and the plates were developed in the descending mode, by eluting with physiological saline buffered with $0.005 \mathrm{M}$ phosphate $p \mathrm{H} 7.2$. 
The developed plates for both classes of sample were viewed after development in a darkened room under the ultra-violet radiation from a Wood's lamp.

2 INFRA-RED SPECTROSCOPY A disc of potassium bromide crystals containing $1 \mathrm{mg}$. of a sample of fluorescein isothiocyanate was placed in a Perkin-Elmer infra-red recording spectrophotometer model 137 , and a record made by pen recorder of the spectrum from $2.5 \mu$ to $15 \mu$.

3 IMMUNOELECTROPHORESIS IN AGAROSE GEL Agarose was prepared by the method of Russel, Mead, and Polson (1964). Microscope slides carrying a layer of $0.8 \%$ agarose gel in barbiturate buffer $p H 8 \cdot 2, I=0.02$, were prepared according to the method of Sheidegger (1955).

The antigen wells were filled with the conjugated globulins under test, and a current of 3-5 ma per slide at a potential difference of 200 volts was passed for 30 minutes. The troughs on the slides were then filled with the appropriate species-specific antiserum prepared by Burroughs Wellcome, Beckenham, Kent, and the slides were set aside in a moist atmosphere box at room temperature overnight. Next morning, the position of precipitin lines was recorded by drawing.

4 ACTIVATION AND FLUORESCENCE-EMISSION SPECTROPHOTOMETRY Equal-strength solutions in ethanol of each of the samples of fluorescein isothiocyanate were placed in the quartz cuvette of an Aminco-Bowman spectrophotofluorometer. The emitted light was measured in arbitrary units at all wavelengths from 200 to $700 \mathrm{~m} \mu$. The maximum peak of emitted light found was then compared at all activation wavelengths over the same range. The wavelength emission curves were recorded with a pen recorder. The process was repeated with equalstrength solutions of the globulin samples in $0.05 \mathrm{M}$ phosphate buffered physiological saline.

\section{QUANTITATIVE ASSAYS}

5 PROTEIN CONCENTRATION AND FLUORESCEIN-PROTEIN ABSORPTION RATIOS Dilutions of 1:50 of the samples in phosphate buffered saline in silica cells were placed in a Unicam SP 500 spectrophotometer and the optical density measured at $280 \mathrm{~m} \mu$ and $495 \mathrm{~m} \mu$. For calculation of the protein concentration it was assumed that all the protein present was globulin and the factor $\mathrm{E} 1 \mathrm{mg} . / \mathrm{ml}$. at $280 \mathrm{~m} \mu=1.24$ od was applied.

6 HEIGHT OF FLUORESCENCE EMISSION PEAKS The curves produced in (4) were compared and the height of comparable peaks was measured in arbitrary emission units. This was related to protein or fluorescein isothiocyanate concentration.

EFFICIENCY OF CONJUGATION OF THE SAMPLES OF FLUORESCEIN ISOTHIOCYANATE

In addition to the quantitative and qualitative assays, an estimate was made of the relative efficiency with which the compounds conjugated. Five per cent. dispersions of each of the samples of fluorescein isothiocyanate were prepared on celite. A globulin preparation was made from normal human serum by ammonium sulphate fractionation followed by repeated dialysis and the $p \mathrm{H}$ corrected to 9.0 with carbonate-bicarbonate buffer. After estimation of the protein concentration it was divided into seven equal parts. A different sample of fluorescein isothyiocyanate celite was added to each of seven dry freeze-drying ampoules (Johnsen and Jorgensen Ltd., London, E.C.4) at the rate of $10 \mathrm{mg}$. for each gram protein, then one of the parts of the globulin solution was added, and the ampoules sealed in a flame. They were then together inverted in a rotator at 3 r.p.m. so that the liquid ran from end to end continuously without foaming. After $30 \mathrm{~min}$. the ampoules were opened and the contents of each passed down Sephadex G25 columns of identical dimensions. The conjugated protein fraction was collected and protein and fluorescein/ protein ratios determined. The fluorescent emitted light at $520 \mathrm{~m} \mu$ of each was measured at an activation wavelength of $288 \mathrm{~m} \mu$ in the Aminco-Bowman spectrophotofluorometer. The amount of emitted light was then related to protein concentration for comparisons to be made.

The process was repeated with a specific high-titre antiserum against Shigella sonnei phase I, and the fluorescein-protein ratios determined. The conjugates were diluted to the same protein concentration and used to stain smears of human faeces containing $S$. sonnei by the method of Taylor and Heimer (1964). Further dilutions were made to determine the lowest protein concentration at which a specific staining reaction could be obtained with each serum.

\section{QUALITATIVE ASSAYS IN SAMPLES OF FLUORESCEIN ISOTHIOCYANATE}

1 BY THIN-LAYER CHROMATOGRAPHY On silica gel six of the seven samples were markedly heterogeneous

\section{TABLE I}

COMPONENTS IN SEVEN COMMERCIAL SAMPLES OF FLUORESCEIN ISOTHIOCYANATE

\begin{tabular}{cccccc}
$\begin{array}{l}\text { Sample } \\
\text { Code }\end{array}$ & F.I.T.C. I & F.I.T.C. II & $\begin{array}{l}\text { Amino- } \\
\text { fluorescein }\end{array}$ & $\begin{array}{c}\text { Nitro- } \\
\text { fluorescein }\end{array}$ & $\begin{array}{c}\text { Free } \\
\text { Fluorescein }\end{array}$ \\
\hline A & Present & Absent & Absent & Absent & Absent \\
B & Present & Present & Absent & Absent & Present \\
C & Present & Present & Absent & Absent & Present \\
D & Present & Present & Present & Present & Present \\
E & Present & Present & Absent & Absent & Present \\
F & Present & Present & Absent & Absent & Present \\
G & Present & Present & Absent & Absent & Present
\end{tabular}

(Table I). Only sample A was homogeneous and appeared to consist of isomer $\mathrm{I}$. The remaining six contained free fluorescein, and both I and II isomers of fluorescein isothiocyanate. Sample D was particularly poor on this test as it contained both aminofluorescein and nitrofluorescein, but relatively little fluorescein isothiocyanate isomer $I$.

The remaining three British samples (B, C and 
E) which appeared to be of intermediate purity, behaved in an identical fashion in this test.

2 BY INFRA-RED SPECTROSCOPY. This technique gave absorption peaks which were related to individual groups within the molecule of fluorescein isothiocyanate. The spectrum of sample A showed many fewer peaks than any of the other samples, and the height of the specific peak for the - NCS group was higher in sample $A$ than in any of the other six. The samples B-G all showed some blurred, broad peaks, strongly indicating impurities. The position and height of the peaks in the curves obtained with the British samples B, C, and E were identical. This indicated that the impurities they contained were present in similar amount in each.

3 BY ACTIVATION AND FLUORESCENCE SPECTRA With the samples of fluorescein isothiocyanate the optimum wavelength for activation was found to be $460 \mathrm{~m} \mu$. This wavelength is not usable for immunofluorescence since it is in the visible range, and the next best wavelength was $370 \mathrm{~m} \mu$. This was the wavelength of activating ultra-violet light at which, for a given amount of energy absorbed from the activating radiation, the amount of emitted light at $520 \mathrm{~m} \mu$ was at a maximum. All samples showed a maximum peak of emitted light at $520 \mathrm{~m} \mu$, but sample D also showed a broad, lower peak between 400 and $490 \mathrm{~m} \mu$ which altered the colour of the light seen by the eye to a brownish tint. A pronounced light-scatter peak in the emission curve for sample $F$ indicated a considerable amount of insoluble material under the conditions of the test. Again the British samples B, $C$, and $E$ had identical emission spectra. The heights of the emission peaks at $520 \mathrm{~m} \mu$ obtained with solutions of equal strength were compared (Fig. 1). The amount of light emitted from sample $A$ was at least twice the next best and seven times as great as that from sample $D$, indicating a considerable amount of impurity in samples B-G.

EFFICIENCY OF CONJUGATION Conjugates of normal human globulin with each of the seven samples of fluorescein isothiocyanate were available in sufficient quantities for instrumental analysis. The emission at $520 \mathrm{~m} \mu$ was read in the spectrophotofluorometer with activation at $288 \mathrm{~m} \mu$ (vide infra) and the protein concentration determined as before. It can be seen (Table II) that the differences in emission of the standard conjugates were less than the differences in emission found in the seven samples of fluorescein isothiocyanate from which they were made, although that prepared from sample A still emitted more light than the others.

With the samples of conjugated globulins from

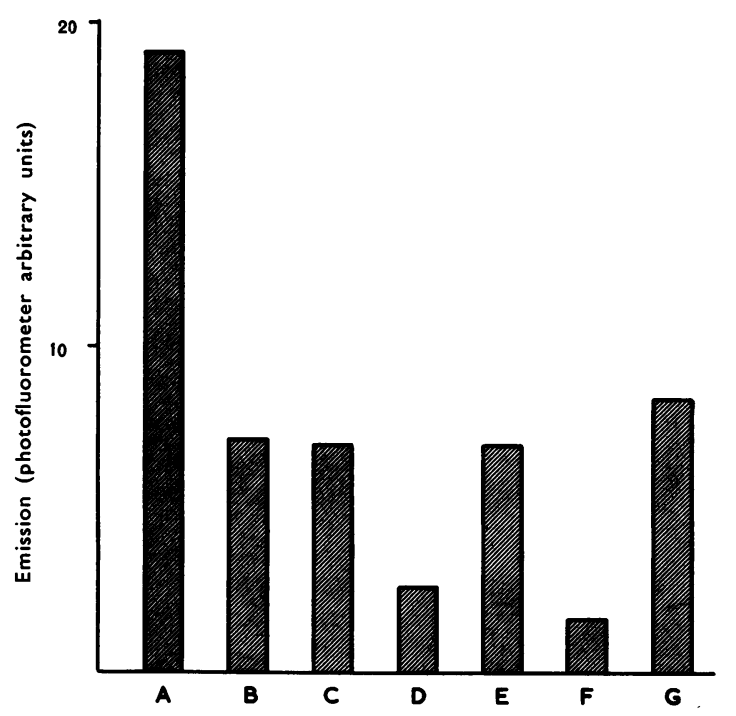

FIG. 1. Relative amounts of emitted light at $520 \mathrm{m \mu}$ from standard solutions $(100 \mathrm{~g} . / \mathrm{ml}$. in alcohol) of seven different samples of fluorescein isothiocyanate on excitation with light at $370 m \mu$.

\section{TABLE II}

EMISSION FROM CONJUGATES OF A COMMON GLOBULIN SOLUTION WITH DIFFERENT FLUOROCHROMES

\begin{tabular}{|c|c|c|c|}
\hline $\begin{array}{l}\text { Conjugate Prepared } \\
\text { with Sample Coded }\end{array}$ & $\begin{array}{l}\text { Emission at } \\
520 \text { mu }\end{array}$ & $\begin{array}{l}\text { Protein } \\
\text { (mg./ml.) }\end{array}$ & $\begin{array}{l}\text { Corrected to } \\
\text { Concentration of } A\end{array}$ \\
\hline $\mathbf{A}$ & $12 \cdot 6$ & $0 \cdot 12$ & $12 \cdot 6$ \\
\hline B & $7 \cdot 6$ & $0 \cdot 105$ & $8 \cdot 2$ \\
\hline C & $7 \cdot 2$ & 0.09 & $9 \cdot 6$ \\
\hline D & 3.45 & 0.08 & $5 \cdot 2$ \\
\hline E & $8 \cdot 1$ & $0 \cdot 105$ & $9 \cdot 25$ \\
\hline$F$ & 9.0 & 0.145 & 7.45 \\
\hline $\mathrm{G}$ & $7 \cdot 8$ & 0.13 & $7 \cdot 2$ \\
\hline
\end{tabular}

antiserum to $S$. sonnei phase I, there was insufficient material available for both instrumental and microscopical examination. It was decided therefore to concentrate on the microscopical investigation, and to dilute the conjugate until no further staining occurred. The slides were examined by two independent observers and the results are shown in Table III. The conjugate prepared with sample A was extremely satisfactory, samples B, C, E, F, and $G$ gave reasonably satisfactory results, although the final dilution figure in all five was lower than with $A$. The conjugate prepared with sample $D$ was so unsatisfactory that it could not be diluted further.

The same technique was used to investigate the specificity of the $S$. sonnei sera conjugated with the different F.I.T.C. samples. Sample D was omitted 
TABLE III

FLUORESCENCE OF $S$. SONHei AFTER STAINING WITH FRACTIONS OF A SPECIFIC ANTISERUM CONJUGATED WITH DIFFERENT FLUOROCHROMES

Conjugate Prepared Protein Concentration of Dilution ( $\mathrm{mg} . / \mathrm{ml}$.) with Sample Coded

\begin{tabular}{lllll}
\hline 15 & 3 & 1.5 & 0.75 & 0.375
\end{tabular}

\begin{tabular}{llllll}
\hline $\mathbf{A}$ & ++++ & +++ & ++ & ++ & + \\
$\mathbf{B}$ & ++++ & ++ & + & - & - \\
$\mathbf{C}$ & ++++ & ++ & + & - & - \\
$\mathbf{D}$ & + & - & - & - & - \\
$\mathbf{E}$ & ++++ & +++ & ++ & + & - \\
$\mathbf{F}$ & +++ & +++ & ++ & + & - \\
$\mathbf{G}$ & ++++ & +++ & + & - & -
\end{tabular}

$+\quad=$ just detectable fluorescence

$++\quad=$ good fluorescence suitable for routine investigations

$+++=$ extremely good fluorescence

$++++=$ excellent fluorescence unnecessarily bright for routine investigations

from this test. Table IV shows that all sera gave fluorescent staining of suspensions of $S$. sonnei in phase I and of $\mathrm{C} 27$ which has a common O-antigenic fraction, but that none of them gave any significant reaction with $S$. sonnei in phase II or with Escherichia coli.

\section{TABLE IV}

STAINING OF RELATED ORGANISMS WITH FRACTIONS OF A $S$. sonnei PHASE I SPECIFIC ANTISERUM CONJUGATED WITH DIFFERENT FLUOROCHROMES ${ }^{1}$

\begin{tabular}{|c|c|c|c|c|}
\hline \multirow{2}{*}{$\begin{array}{l}\text { Conjugate Prepared } \\
\text { with Sample Coded }\end{array}$} & \multicolumn{4}{|c|}{ Smear Prepared from } \\
\hline & $\begin{array}{l}\text { S. sonnei } \\
\text { phase I }\end{array}$ & $\begin{array}{l}\text { S. sonnei } \\
\text { phase II }\end{array}$ & $C 27$ & $\begin{array}{l}\text { Escherichia } \\
\text { coli }\end{array}$ \\
\hline $\mathbf{A}$ & $++t$ & - & +++ & 一 \\
\hline $\mathbf{B}$ & ++ & - & + & - \\
\hline $\mathrm{C}$ & + & - & + & - \\
\hline $\mathbf{E}$ & ++ & - & + & - \\
\hline $\mathbf{F}$ & $+t$ & - & + & - \\
\hline G & ++ & - & + & - \\
\hline
\end{tabular}

${ }^{1}$ All at $3 \mathrm{mg} . / \mathrm{ml}$. protein concentration

Although this test is more an evaluation of the specificity of the serum than of the conjugate it was thought of value to include the result, since it indicates that with none of the conjugates was there any measure of decomposition of the conjugate into free fluorochrome and protein after conjugation.

\section{RESULTS IN SAMPLES OF COMMERCIAL CONJUGATED GLOBULINS}

1 THIN-LAYER CHROMATOGRAPHY Sephadex G200 thin layers separated the components of the conjugated globulin solutions into spots in three positions. The first spot, at the origin, represented free, uncoupled (or decoupled) fluorochrome, the second was conjugated albumin, and the third spot, which ran furthest, was the group of conjugated globulins.
The protein spots were sharply defined when viewed under ultra-violet light. Table $\mathrm{V}$ summarizes the results.

\section{TABLE V}

COMPONENTS REVEALED IN COMMERCIAL CONJUGATED GLOBULIN SOLUTIONS BY CHROMATOGRAPHY ON SEPHADEX G200

\begin{tabular}{llll} 
Sample Code & $\begin{array}{l}\text { Free } \\
\text { Fluorochrome }\end{array}$ & Albumin & Globulin \\
\hline I & Absent & Weak & Strong \\
II & Trace & Absent & Strong \\
III & Trace & Strong & Strong \\
IV & Trace & Strong & Strong \\
V & Trace & Strong & Medium \\
VI & Absent & Trace & Strong
\end{tabular}

Samples I, II, and VI were reasonably satisfactory, but the remaining three contained both conjugated albumin and free fluorochrome. Samples IV and V were particularly unsatisfactory since the albumin spot in both was at least as strong as that for globulin.

2 IMMUNOELECTROPHORESIS Precipitin lines were produced in all the slides in positions for the serum components shown in Table VI.

Sample II was the only one which was uncontaminated with conjugated albumin.

\section{TABLE VI}

SERUM PROTEINS IN SAMPLES OF COMMERCIAL CONJUGATED GLOBULINS

\begin{tabular}{ll} 
Sample Code & Serum Proteins Present \\
\hline I & IgG, IgM, small amount albumin \\
II & IgG, IgM \\
III & IgG, IgM, albumin \\
IV & IgG, IgM, $\alpha$ and $\beta$ globulins, strong albumin \\
V & IgG, IgM, $\alpha$ and $\beta$ globulins, strong albumin \\
VI & IgG, IgM, $\alpha$ and $\beta$ globulins. trace albumin
\end{tabular}

${ }^{1}$ For explanation of new nomenclature for immunoglobulins see W.H.O. (1964), Bull. Wld. Hlth. Org., 30, 447.

3 ACTIVATION AND FLUORESCENCE EMISSION PEAKS With the samples of commercial conjugated globulin the activation spectra showed maxima at $495 \mathrm{~m} \mu$ with secondary maxima at $288 \mathrm{~m} \mu$. In samples II, IV, and V there were additional peaks of activation between 288 and $495 \mathrm{~m} \mu$. The secondary maximum therefore had moved from $375 \mathrm{~m} \mu$ which was the secondary maximum for free F.I.T.C. to $288 \mathrm{~m} \mu$.

A quantitative comparison of emission at $520 \mathrm{~m} \mu$ for equal strength solutions of the samples is shown in Figure 2. Subsequent investigations revealed that samples IV and V contained unexpectedly large amounts of protein, presumably derived from the liver powder with which they had been absorbed by the manufacturers, and so this quantitative 


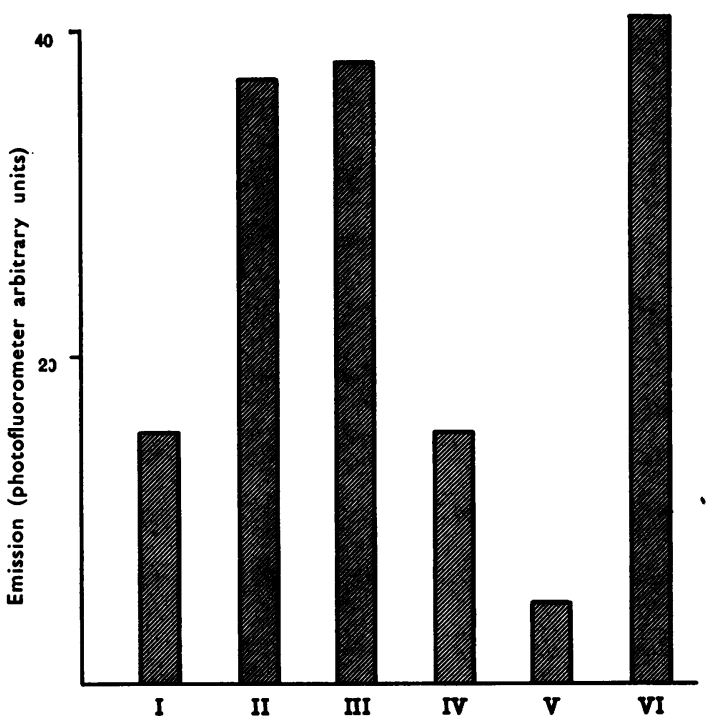

FIG. 2. Relative amounts of emitted light at $520 \mathrm{m \mu}$ from standard solutions $(100 \mathrm{mg} . / \mathrm{ml}$. protein) of six different samples of commercial conjugates, on excitation with light of $288 \mathrm{m \mu}$.

comparison may not have the same relevance as that shown in Figure 1.

4 PROTEIN CONCENTRATION AND FLUORESCEINPROTEIN RATIOS The $280 / 495 \mathrm{~m} \mu$ ratios of the commercial globulin solutions are shown in Table VII.

\section{TABLE VII}

PROTEIN CONCENTRATION AND FLUORESCEIN-PROTEIN RATIOS OF COMMERCIAL CONJUGATED GLOBULIN PREPARATIONS

\begin{tabular}{lllll}
$\begin{array}{l}\text { Sample } \\
\text { Code }\end{array}$ & \multicolumn{2}{l}{$\begin{array}{l}\text { Optical Density of } a \\
\text { 1/100 Dilution }\end{array}$} & $\begin{array}{l}\text { Original Protein } \\
\text { Concentration }(m g . / m l .)\end{array}$ & $\begin{array}{l}\text { Ratio } \\
\text { (protein = 1) }\end{array}$ \\
\cline { 2 - 3 } & $280 m \mu$ & $495 m \mu$ & & \\
\hline I & 0.21 & 0.08 & 26.0 & 0.38 \\
II & 0.14 & 0.175 & 17.3 & 1.25 \\
III & 0.18 & 0.26 & 22.2 & 1.45 \\
IV & 0.47 & 0.61 & 58.4 & 1.3 \\
V & 0.6 & 0.47 & 74.5 & 0.78 \\
VI & 0.375 & 0.215 & 30.2 & 0.575
\end{tabular}

The extremely high figures for protein concentration in samples IV and V were rather surprising when compared with the results obtained by the immuno- electrophoresis and thin-layer techniques. These two samples were the only two which had been absorbed with liver powder by the manufacturers, and it seems likely that some protein had dissolved from the liver giving a false high result.

\section{DISCUSSION}

Three of the four British samples of fluorescein isothiocyanate gave identical results in all the tests, and appeared to contain equal amounts of the same impurities. Despite differences in retail price, therefore, it seemed likely that these materials came from the same manufacturer, even from the same batch. However, all three formed acceptable conjugates, though these were not so good as that made from one of the American samples, which was much more expensive. The fourth British sample was of very poor quality and could not be considered seriously for fluorescent antibody techniques. The two remaining American samples both gave acceptable conjugates but were little different from the three better British products.

For the present, therefore, the choice of F.I.T.C. seems to be between a British manufacturer whose product is distributed by three retailers and a better, though more expensive, American product. When, however, account is taken of the reduced amount of the American material required for conjugation, the price differential is greatly reduced.

Amongst the samples of commercially conjugated globulins none was entirely satisfactory. Samples I and VI contained conjugated albumin; sample II contained free fluorochrome; and samples III, IV, and $\mathrm{V}$ contained both conjugated albumin and free fluorochrome. These impurities could have been removed by relatively simple procedures.

My thanks are due to Dr. J. Bridges of St. Mary's Hospital Medical School, who by permission of Professor R. T. Williams carried out the infra-red and fluorescence measurements, and to Mr. G. V. Heimer of the Central Public Health Laboratory, who prepared, stained and assessed the $S$. sonnei smears.

\section{REFERENCES}

Russell, B., Mead, T. H., and Polson, A. (1964). Biochim. biophys. Acta (Amst), 86, 169.

Scheidegger, J. J. (1955). Int. Arch. Allergy, 7, 103.

Taylor, C. E. D., and Heimer, G. V. (1964). Brit. med. J., 2, 165. 